\title{
sobre: Una poética de la convocatoria. La literatura comunista de Raúl González Tuñón, de María Fernanda Alle. Rosario:
}

Beatriz Viterbo, 2020.

\author{
EMILIANO RODRÍGUEZ MONTIEL Universidad Nacional de Rosario - CONICET, Argentina
}

ORCID 0000-0002-8050-9151

emiliano.r@conicet.gov.ar

\section{El Tuñón de Alle}

Si la literatura argentina es, siguiendo las coordenadas del GPS Viñas, el relato más o menos intrincado de las opciones morales y estéticas que los escritores toman frente a la realidad política de su tiempo, nuestro siglo veinte —olvidando sus minucias e inflexiones, abusando de este principio ordenador - se abre y cierra en el antagonismo de dos tomas de posición hoy arquetípicas: la de Lugones (reaccionario e ideólogo del golpe de Uriburu, sintetiza la figura del «escritor oficial») y la de Walsh (poniendo al Estado como criminal y a la ficción como escenario de la praxis testimonial, ilustra la idea de «escritor comprometido»). Dos maneras clásicas de tensionar literatura y política cuya avenida del medio, esa que va de 1930 a 1970, bien puede ser ocupada, en tanto arista y episodio singularísimo de esta tradición, por la literatura comunista de Raúl González Tuñón. El texto-tutor que acompaña esta obra, el libro albacea cuya aparición augura —al igual que el Puig de Alberto Giordano, el Aira de Sandra Contreras y el Saer de Rafael Arceun destino de referencia obligada, es, claro está, Una poética de la convocatoria de María Fernanda Alle. Por la destreza con la que hace convivir bajo una misma argumentación a todos los materiales del Planeta Tuñón (léase ensayos, poemas, crónicas, relatos, artículos y notas periodísticas), por el afán de claridad que humea sin extinguirse durante las casi 500 páginas que conforman este tratado sobre cómo leer meticulosamente una literatura que se piensa inescindible de su finalidad política, y, sobre todo, por la hipótesis que hace fulgurar en 2020 a esta literatura siamesa (a saber: que la literatura comunista de Tuñón, «confiada en su capacidad de transformación del mundo», «tiene por fin exhortar a la lucha, sumar voluntades a las causas partidarias y ponderar las acciones del partido frente a cada enemigo ocasional»), el libro de Alle ostenta, desde el diseño de tapa de Nahuel Fretes, su naturaleza de texto fuente, texto a copar de ahora y para siempre la unidad de reúsos críticos del realismo socialista en los programas de teoría literaria (33).

\footnotetext{
Para citar este artículo: Rodríguez Montiel, E. (2020). Sobre: Una poética de la convocatoria. La literatura comunista de Raúl González Tuñón, de María Fernanda Alle. El taco en la brea, 12 (junio-noviembre). Santa Fe, Argentina: UNL. eoo22 DOI: 10.14409/tb.v1i12.9700
} 
Son tres las partes que enderezan este ensayo y son tres las imágenes que orquestan la figura del Tuñón comunista. Extrayéndole al máximo el jugo a la célebre noción de María Teresa Gramuglio, Alle dispone toda la materia prima del poeta al servicio de una interpretación:

las imágenes de escritor que Tuñón construye en sus textos proyectan los lineamientos de una poética, a la que defino como una poética de la convocatoria, que liga, de manera indisoluble, la práctica literaria con la política partidaria, de modo tal que el valor de la literatura termina por identificarse con su potencial para cambiar el mundo. (21)

Así, ligando de manera inteligente no solo «los estados del campo literario, sino también los programas de acción políticos y culturales del PC», Alle labra una exégesis del semblante Tuñón por partida triple. La primera, conjurada bajo la fórmula «el tránsito desde el muchacho marginal y bohemio al escritor comprometido con la causa revolucionaria», explora la faceta vanguardista del autor, aquella que, domiciliada en la mitad de los años 30, intenta darle un «vuelo lírico» a la revolución social afiliándola al sueño histórico de las vanguardias:

La búsqueda que emprende Tuñón es la de un arte al servicio de la revolución que retome el proyecto martinfierrista pero que lo sobrepase, o lo complete, en tanto que ya no está en juego la consigna de renovar el arte sino de «cambiar la vida», es decir, romper, como quería la vanguardia, con la incomunicación existente entre el arte y la vida. (73)

El leviatán, bête noire o principal horizonte de confrontación de esta concepción de izquierda será, por su ADN burgués, neutral y aristocrático, la revista Sur y en especial su directora, «la señora Victoria Ocampo» quien, «muy rica y muy relacionada, poseedora de una de esas culturas frívolas, inútiles, no muy grandes por cierto», «no ha hecho nada por la cultura argentina», «ni una sola página perdurable» (76).

Ahora bien, con la imposición del realismo socialista en 1934 —el mismo año, aclara Alle, en el que Tuñón se alistaría al partido-, la amistad entre el PC y las vanguardias quedará sin efecto, provocando una verdadera trasmutación en la escritura del argentino, no solo a nivel compositivo («su escritura se vuelve más enfática, seria y solemne, menos dispuesta a la búsqueda de la experimentación formal») sino, antes bien, a nivel funcional: arriadas las banderas vanguardistas, la política literaria de Tuñón queda, de ahora en más, supeditada a los imperativos del partido (86).

El caso de Tuñón es, entre mediados de los años 30 y finales de la década del 50, el de un escritor del partido cuya función, en el esquema de tareas pautadas por la estructura partidaria, será la de convocar a la lucha o, dicho de otro modo, la de sumar voluntades a la causa a través de la escritura literaria. (86)

De allí que la imagen de escritor que proyecte en este segundo momento no sea ya la de un «yo» en reconversión (de poeta marginal a poeta político) sino la de un «nosotros fraternal» cuyo propósito último es, al mismo tiempo que definirse en oposición a un «ellos» abominable (burgueses, fascistas, nazis, peronistas, oligarcas), acudir a la cita con la Historia (96).

En un más acá del presente, la tercera y última imagen reverbera, entre el reencantamiento y el homenaje, la reivindicación y la admiración, a un Tuñón «maestro» que entre 1957 y principios 
de los 70 guía virgilianamente a los jóvenes intelectuales nucleados en la revista y editorial $L a$ rosa blindada y el colectivo de poesía Pan duro:

la recuperación de su figura por parte de los jóvenes favorece (o provoca) una reelaboración de la poética vanguardista de los años 30, aunque ahora, desde una mirada de la memoria que tiende lazos hacia el futuro, en tanto la poesía deviene en legado de una experiencia de lucha destinada a los jóvenes. (38)

La razón de esta exhumación, de esta recuperación y puesta en valor de la empresa Tuñón se debe, al decir perspicaz de Alle, a aquello por lo que hoy es considerado y tasado como su mayor herencia: una actitud, a la vez estética y política, que hace cuajar, a la manera de un reloj suizo, militancia y escritura poética. Eso que, en palabras del mismo Tuñón, toma el nombre de «realismo romántico»: ni arte puro ni arte de propaganda, ni poesía burguesa ni poesía social, ni arte por el arte ni literatura aunada únicamente al reflejo y a la denuncia; de lo que se trata, antes que reproducir con la cabeza gacha las instrucciones del realismo socialista, es de apostar a «una literatura que sea realista sin abandonar la afirmación de la imaginación y la creatividad» (246). Equilibrar «la forma y el fondo», «la calle y el gabinete», «la realidad y la fantasía»: tal es, en esencia, el bálsamo que los jóvenes de izquierda buscan en los sesenta, el motivo que explica el entusiasmo con el que reeditan su obra temprana.

«Cuando sepamos esto, todo lo que vamos a saber» reza la frase de Arlt con la que Alle inaugura el libro. Sin esfuerzo, satisfaciendo incluso a los bibliófilos más glotones y diversos (los críticos vitalicios del Club Tuñón, los historiadores ávidos en dar con un archivo ordenado, los militantes del PC deseosos de instruirse con una guía local, los amantes melancólicos de la Segunda Guerra mundial, los estudiantes de Letras ansiosos por fundar la peña Lukács y los lectores comunes como yo, que leímos siempre al comunismo como un gran relato de ficción), basta con solo hacer zapping por el índice para darnos cuenta de hasta qué punto esa máxima artliana, puesta allí para graficar un entusiasmo por el conocimiento del que fui testigo incontables veces, funciona a la perfección si la invocamos al revés, cuando tengamos el libro sobre nuestras manos, inquietos ya por aprender del Tuñón de Alle. 